\title{
THE GEOPOLITICS OF IRAN ACCORDING TO THE THEORY OF GEOGRAPHICAL BUFFER SPACES
}

\section{Syrus Ahmadi Nohadani ${ }^{1}$}

\section{Introduction}

Many countries have served as buffer states since the evolution of the state concept early in mankind's recorded history. Where and the whys they came to be is, of course, clearly within the scope of geography (Chay I986,II). At regional or global levels, two or more powers view to control the world and geopolitical areas. They are trying to achieve an extended goal, i.e. ruling and infiltrating geographical spaces. In the rivalry pattern between two greater powers, their geographical space is separate from each other. Between the two, there is a space called "the vacuum space"; a geographic space without much power. Geopolitical boundaries of these two powers should not contact because in such a case, the possibility of conflict can arise. Powers become so sensitive to this space that they counteract their struggles for this space. They react immediately with each step and this buffer space turns into a control, maintenance and prudence space. Buffer space cannot protect or vaccinate itself. What prevents this space from collapsing is the action and rivalry of these powers. The two great powers are intended to attract the partners, and they arrange their team. Even it is possible that the team is not aware that it is misused by great power(s), or it hates this issue of being buffer space. The members of the team are selected from citizens of the buffer space. Great powers are aware of each other behaviors and react to the rival's steps.

Iran has been a buffer space during the two last centuries. There have been two great powers in the two sides of Iran. Land power in North and sea

I Assistant Professor, Political Geography Dpt, Tarbiat Modares University, Tehran, Iran.

E-mail: sahmadi@modares.ac.ir 
power in South; the two powers have vied, continuously. The two powers have always formed their team in Iran (Hafeznia 2009, 5). This pattern has been repeated and during the history Britain and Russia, and then Soviet Union and the US and Russia and the US have vied in Iran. In the two last centuries a geopolitical competition pattern in global level is reflected in Iran, and the internal political situation of Iran is a reflection of the pattern of competition in global level. Buffer states are considered as small states but geographically they are not. Average or large countries in terms of population and extent can also serve as buffer states. According to Thomas Ross "Of the 200 or so national political entities on the planet today, at least thirty-two have at some period during this century served as buffer states (Ross I986, 20), and more interestingly, most of them are located in Eurasia. Political elites of buffer or quasi-buffer states often based on their countries' foreign policies show tendency toward one of the two powers which leads to further weakening of these states and they become tools for powers in extending their sphere of influence. Most of the buffer states follow the policy of neutrality in order to keep the possibility of war between the great powers at a distance. In some special situations buffer spaces are occupied by the great powers, i.e. Afghanistan, Lebanon, Cambodia and Iran (that were occupied by Russia and Britain in the World War II). When one of the great powers is weakened, the other power tries to occupy the buffer space, for example the case of Afghanistan, Lebanon.

Although buffer states, as valid functional elements, exist in international relations, there is a need for redefining buffer spaces. Thus, we try to explain the structural-functional characteristics of buffer spaces.

The main objective of the research is to explain different functions of the buffer space: for this reason, functions of the buffer space are investigated. The research main question is that what are the nature, functions, characteristics and political behavior of a geographic buffer space? (continues on the next page) 


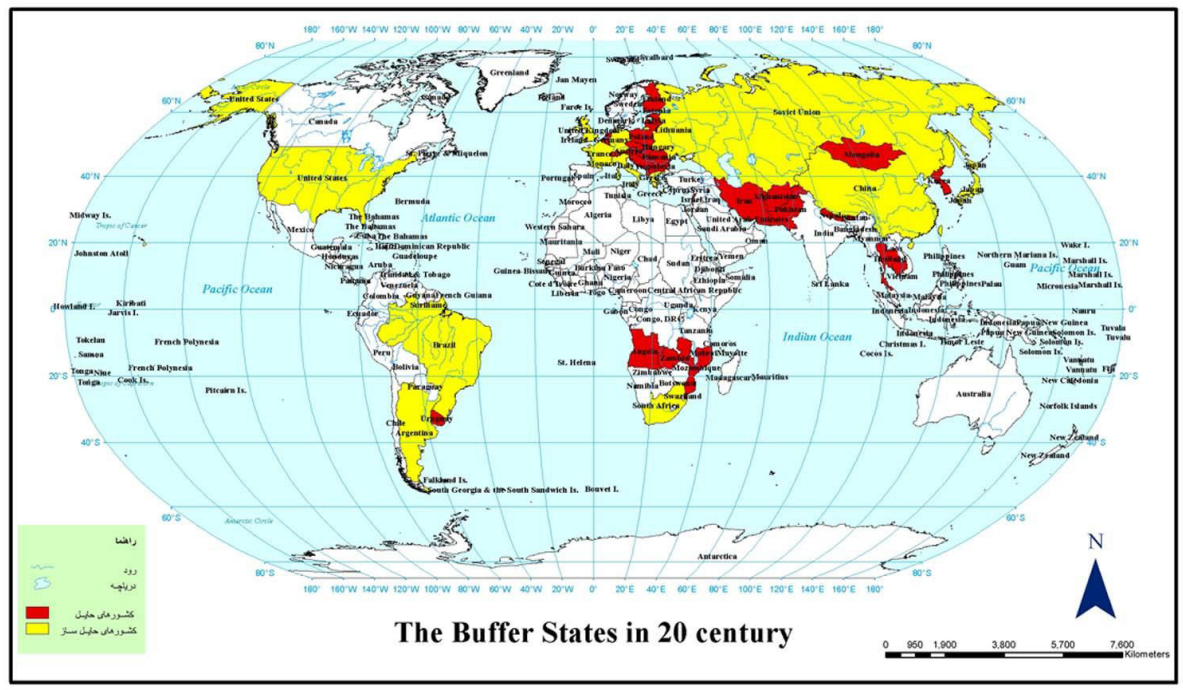

Figure 1. Buffer states in the 20th century

Source: (author)

\section{Buffer Geographic Space Definition}

The main indicators and characteristics of the buffer space are:

I. It is located between two rival powers;

2, Buffer, is a small and weak state in the global system;

between two hostile powers;

3. Creating geopolitical balance and reducing conflicts

4. Neutrality in foreign affairs;

5. Being independent and having political sovereignty;

6. Strategic importance for great power created buffer space.

In order to become a buffer state, a country should have the above characteristics and could be included in the above-mentioned definitions. According to the provided discussions, it can be concluded that buffer space is a:

Geographical space including one or more independent political units, but neutral, and is lying between two or more competing powers or their sphere of influence or between rival or greater power blocs and separates these two and reduces the conflict in a way that they have agreed on its buffer condition. 


\section{Figure 2: Pattern of buffer space}

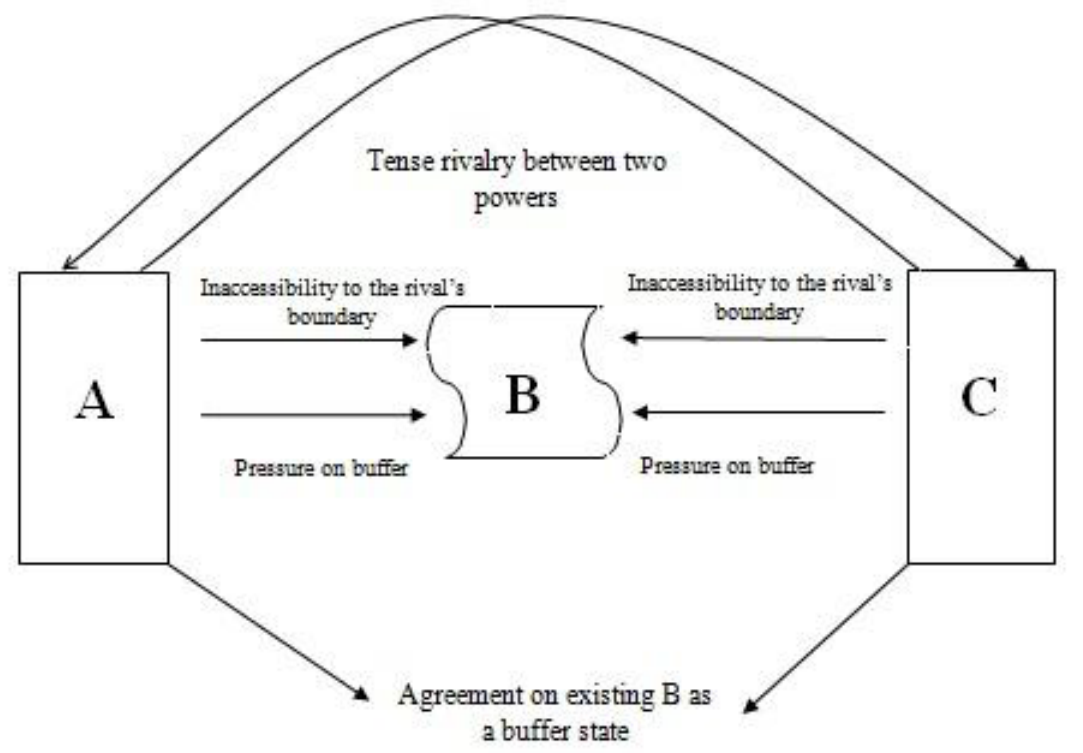

$A=$ buffered power or its sphere of influence; $C=$ buffered power or its sphere of influence; $\mathrm{B}=$ Buffer space

A buffer state is seen by politicians in different situations in different ways; sometimes as a highway to cross and sometimes as a launching pad for further developments (Wight I995, I60-I6I, Turmanidze 2009, 4I). Increase in the rivalry of the two great powers in the buffer state causes the buffer space to be in an underdog situation. Because of the weakness, the buffer state cannot change the powers policies or confront with their policies.

\section{The Research Method}

The data gathering procedure is based on library and field findings. The number of samples is 83 experts in the fields of Geography, Political Geography, International Relations, Political Sciences, Social Sciences, History and Strategic Sciences. In terms of nationality, 7I percent of respondents were Iranian and 29 percent were foreigners. The research sample is selected randomly, and the results are used in the research findings 
section. The research is based on the investigation of the process of formation, characteristics and functions of the "buffer situation of Iran". 40 variables including 6 variables in the process of formation of buffer spaces, I2 variables in relation with characteristics of buffer spaces and 22 variables in relation with the functions of buffer space in two internal and external dimensions are characterized using library references.

Filed findings related to the functions of "buffer situation of Iran" are demonstrated one by one using T-test in SPSS. The average of the variables of functions of "buffer space of Iran" is categorized in three categories including high important, middle important and low important using K- Means Cluster Analyze.

\section{Geographic and Historical Characteristics of Iran}

Iran is located at the Southeast of Asia, and is limited from north to the Caspian Sea, and from south to Persian Gulf, Oman Sea and Indian Ocean. The location of Iran has been a part of regional and global strategies in geopolitical theories (Ahmadi \& Parsaeei 2005, 277-297). Today, there are some geographic regions which have political importance and are an arena of local, regional and global rivalries. Geopolitical regions around Iran are as follows: I. Central Asia, Caspian Sea and the Caucasus in the north; 2. The Indian subcontinent and Afghanistan in the East; 3. The Indian Ocean in the South East; 4. Persian Gulf and Oman Sea in the south; 5- Turkey and Arab region in the West of Iran.

These regions have some geopolitical sub-regions. For example, the North of Iran is formed from three Geopolitical sub-regions including Central Asia, Caspian Sea and the Caucasus, it has a key role in communication between these sub-regions. In general, the geographic location of Iran is a mixture of communicational, buffer, geopolitical, geo-economic and geostrategic locations. The mixture of these locations has given a unique situation for Iran. This situation, from one hand can act as a guarantee of stability and economic development, and from the other hand can bring instability, insecurity and loose of opportunities and capacities (Ezati and Yazdanpanah 2007, 69), and affect internal and external political issues of the state and also strategies of regional and global powers (Malakootiyan 2004, 219). In spite of all technological evolutions, the experience of the past wars showed that when a state have strategic location, it cannot keep itself from global revolutions away or in other words take isolation policy, because it would be a part of a strategy and in particular military strategy, and it should try to act appropriately by understanding its location as a strategic actor, and 
try to benefit from geographic location in order to development of the country (Ezati 2003, 78). This situation has not been understood in the two last centuries by Iran, and if it has been understood, a comprehensive action has not been taken and Iran has been an arena for global powers rivalries.

The research is intended to focus on the political evolutions of Iran in the two last centuries since its buffer situation affected the political life of the state. In this period, Iran was amongst the competition of global powers strategies and had played the role of buffer in the process of competitive behaviors global powers. The competition of global powers, Britain and Russia, corresponded with exertion of dominance, weakening and disabling the state structure in the first half of the 2oth century (Fouler I994, 23). This situation is a new experience in political geography and geopolitics that is resulted from powers rivalry and engaged Ghajar, Pahlavi and Islamic republic of Iran states. In general, this period has been started from I800 (Britain dominance on India and Russia's attack on Iran). The research focus on the period from I80o to ig89 the collapse of the Soviet Union.

\section{Research Findings}

The buffer situation of Iran in the two last centuries among powers competition namely between Britain/ Russia and then the US / Russia brought a difficult and hard situation for Iran, and Iran was struggling to be alive. It can be claimed that the study of Iran's contemporary history would be incomplete without considering the role of great powers and from the geopolitical perspective.

In the last two centuries, relations with Russia and Britain and then the US / Russia which followed some interests in Iran were the main important issues in the foreign policy of Iran. As Malekoshoaraie Bahar put it: Iran looks like a person who had a rope on his neck and two persons draw the rope from two sides and it was floundering (Manshoor Gorgani I989, I7). Iran's role was more passive and this role was imposed by great powers on Tehran. In fact, the disability of Iran was so significant that it came the time when Russia and Britain completely understood this situation and attacked on Iran and divided Iran between themselves without even any reaction from the Iran's side. This situation continued until the end of Cold War and Iran was buffered between the USSR and the US during the Cold War.

In this study, using library references, variables for the formation, features and functions of buffer space were identified as follows. 


\section{Buffer Space Formation}

The process and wherefores

I. Existence of two hostile powers: (Ross I986, 26). (Ziring I986, I53)

2. Existence of a weak space between rival powers: (Chay I986, I92).

3. Powers tendency to expand geographic or geopolitical boundaries and not to approaching rival to their borders: (Ziring I986, I55).

4. Failure of powers in attracting buffer state

5. Rivalry of powers and weakness of buffer space: (Partem I983, 3).

6 . Great powers agreement on the creation of buffer space and nonencroachment on the buffer space: (Ahmadi 2013B)

Figure 3. Iran in the Great Game and the division of Iran into three regions in the 1907 treaty of Russia and Britain
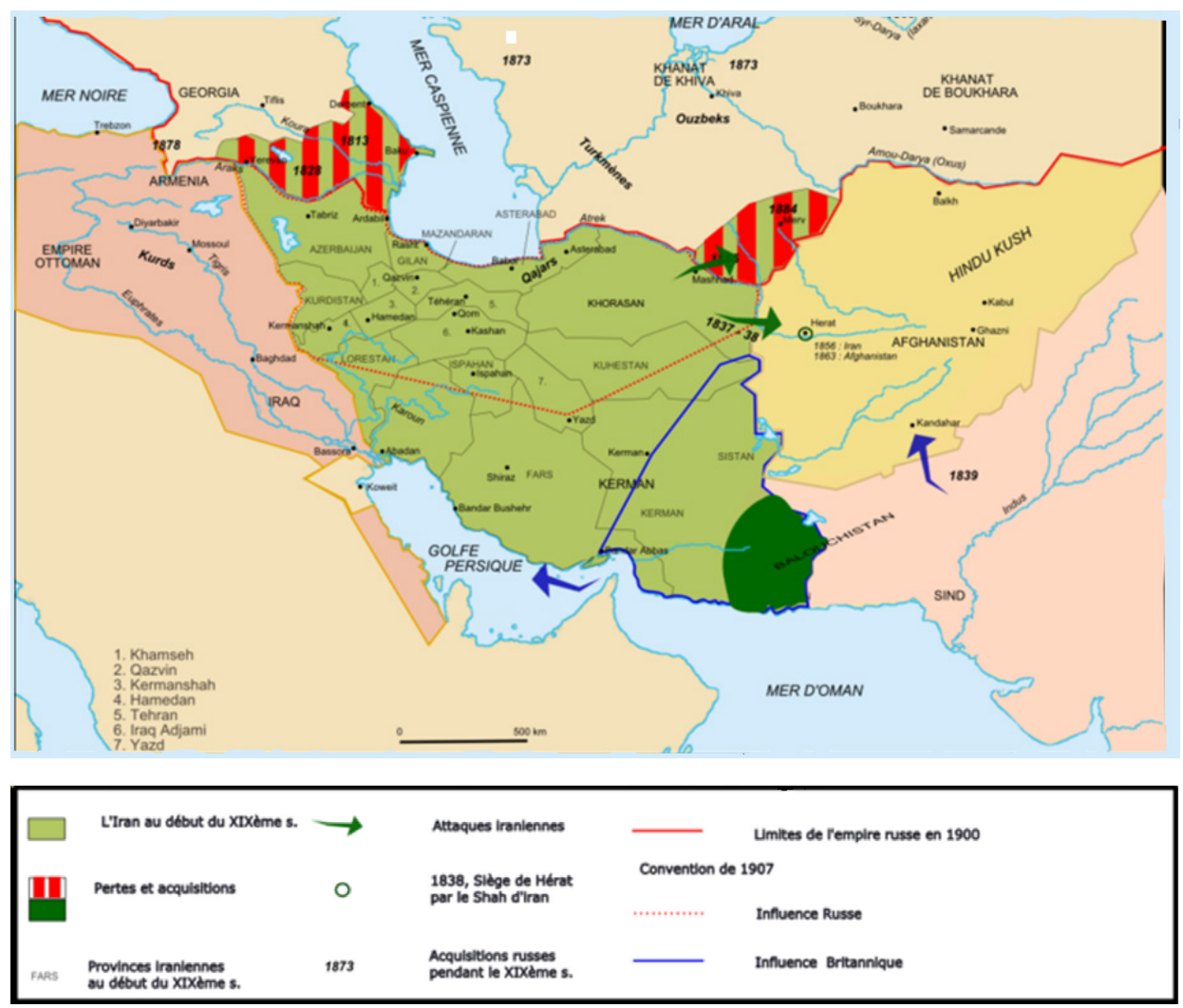


\section{Characteristics of Buffer Space}

I. Geographic location

2. Geographic content

\section{Political Characteristics}

I. Independence of country (Ali Soofi 2006, I30)

2. Neutrality Policy and inclination to third power: (Kempp 2008). (Maila i986, 30).

3. Distribution of power in buffer space (existence of great powers and the weak space). (Hannah I979, I88, in Jenkins I986, I87).

4. Powers triumph to keep the buffer space weak

Figure 4. The elementary pattern of buffer space

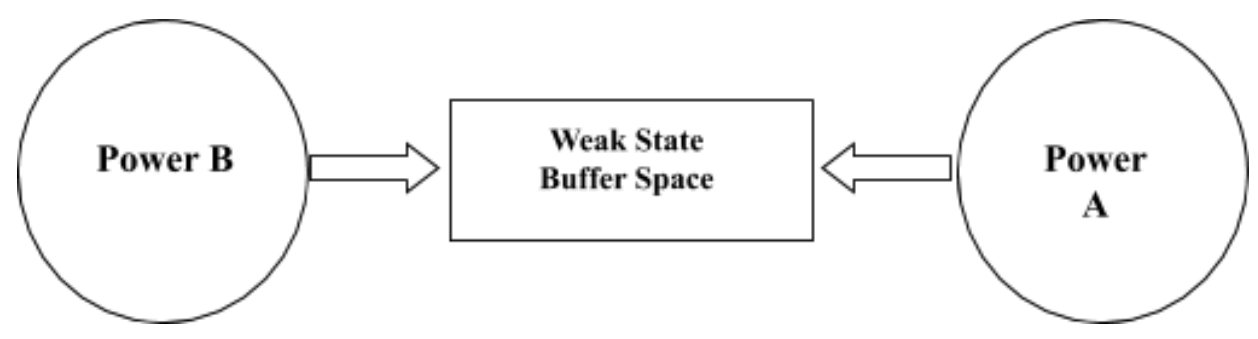

\section{Geopolitical Characteristics}

I. Powers competition in the buffer space

2. Acceptance of buffer space by buffered powers (Turmanidze 2009, 48 in Rondeli 2003, I65)

3. Strategic importance of buffer space for rival powers (Nezio I984, I22) (Warrin I9I8, 87)

4. Tendency of powers for adding buffer space into their defense system (Hooshang Mahdavi 2009, 225).

\section{Economic Characteristics}

I- Low economic growth, loss of geopolitical and geo-economic interests of buffer (Katoozian 2010, 75). 


\section{Functions of buffer state}

\section{Functions in external dimension}

I. Peace maintenance (Ross I986, 25);

2. Encouraging buffer state to incorporate into the alliances desired of buffered states (Fouler i994, 256);

3. Negative reaction of buffered states toward buffer space relation with other powers and in particular third power (Ahmadi 2015);

4. Powers sensitivity towards rivals policies and actions in buffer space: (Katoozian 2010, II9);

5. Maintaining interests of powers in global arena: (Ziring I986, I53).

\section{Functions in internal dimension}

\section{I) Government Level}

I. Continuous intervention in buffer space (Corm 2007, 4);

2. Political inclination of elites and political forces to one of the parts (Abrahamian 2005, I47);

3. Political isolation of buffer state (Ziring I986, I57);

4. Challenges of political regimes of the buffer (political, security and social instabilities) (Maila I986, 38-39) (Fox I959;)

5. Lack of functional solidarity of the state (Bashirie 200I, 25);

6. Following de-utilization policy (Nezio I984, I65);

7. Reactive political decisions (Turmanidze 2009, 25);

8. Border disputes with the neighbors and regional conflicts with neighboring countries;

9. High military costs of buffer state; (Ziring I986, I56).

\section{2) Social level}

Io. High social, political, economic, cultural vulnerability in the buffer state (Katoozian 2010, 70);

II. Expectation of buffer space residents great powers settle their problems and repel the other powers pressures;

I2. Cynical attitude of residents in the buffer zone toward greater powers (Ghafari Hashtjin 2003, 22-33);

I3- Cynical attitude toward that do not have sovereignty and self- 
determination right (Fouler, I994, 23);

I4. Cynical attitude toward central government (Fox I959);

I5- Growing nationalism and radical movements (Jenkins I986, I80);

I6- Tendency of people for isolation and seclusion in the buffer space (Tulchin I986, 213);

I7- Cynical attitude toward political players (Ahmadi 20I5);

\section{Figure 5. The pattern of the buffer space}

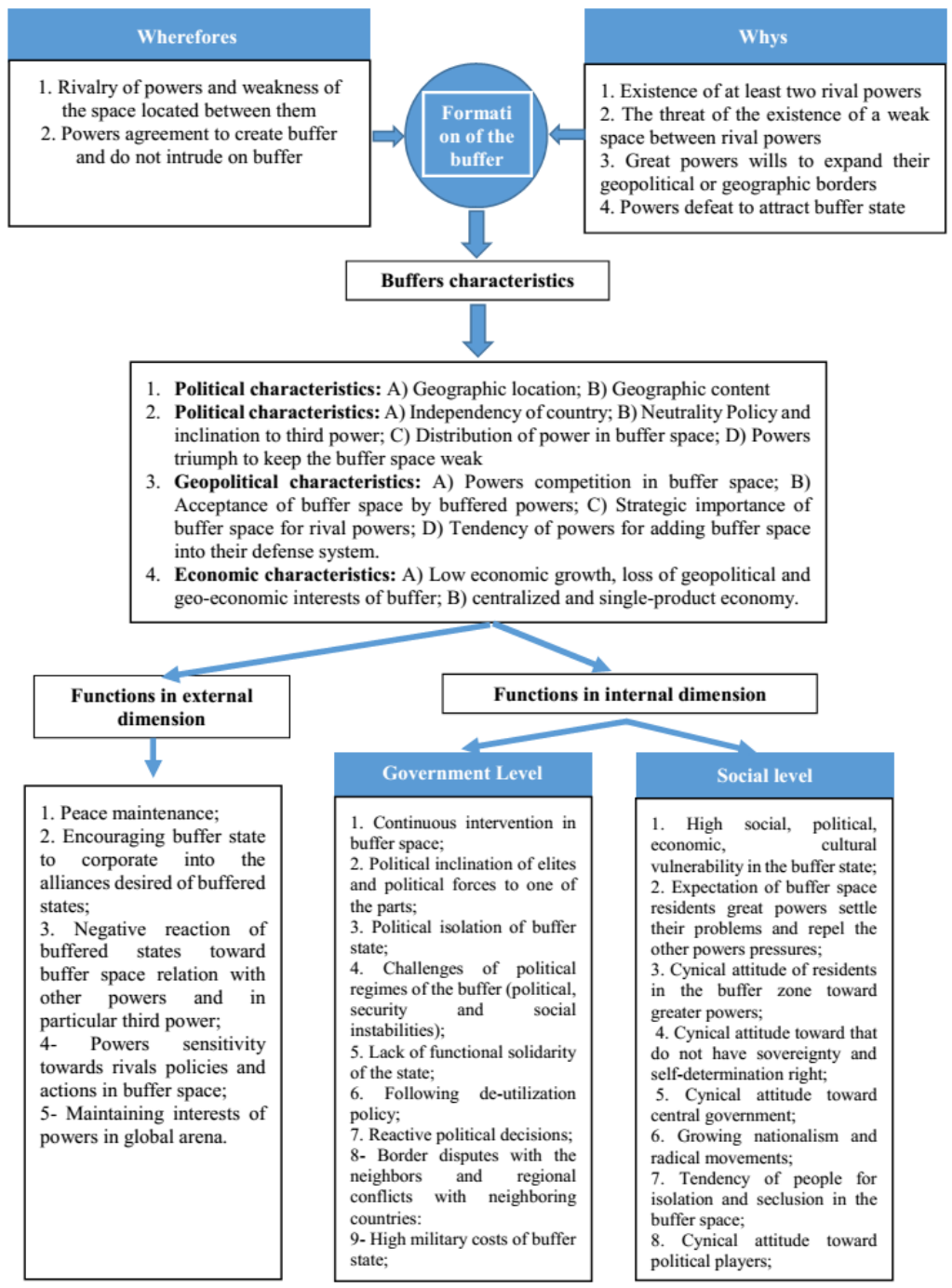

Source: (Ahmadi 2015, 28) 


\section{Debate and Concluding}

The existence of two rival powers is required to form a buffer space. Korea, Vietnam, Belgium, Lebanon, Afghanistan, Iran and other buffers have been located between two or more great powers which converted these states to buffer space. Sometime, buffers are located among several powers like Lebanon that is under pressure of regional powers (Israel/Syria), global powers (Russia/the US) and supra-regional powers (Iran/Saudi Arabia) and is a multilevel buffer.

In the last two centuries, Iran has been buffer between Britain and Russia, then between Britain and Soviet Union, then between the US and Soviet Union and finally between Soviet Union and the US. The buffer state is a space lying between two or more competing powers which separates these powers and reduces the conflict in a way that they have agreed on its buffer condition.

Russia and Britain were in the Iranian borders, and saw the occupation of Iran and Afghanistan by the other rival as a strategic threat to itself. Also, Russia and Britain could not occupy Iran, and they need to keep Iran neutral between their sphere of influence. In the Igth century and first of 2 oth century, Britain intended to move from Indian borders toward northwest to approach to Russia's borders, and Russia intended to approach to Indian Britain borders. The result of competition of these powers was the separation of some territories from Iran, but the main land of Afghanistan and Iran were remained independent and buffer in order to reduce the possibility of conflict between these powers. Hence, Russia and Britain signed an agreement in I834 and agreed on the independency and territorial integrity of Iran as a buffer state between themselves. Also, they signed the treaty of I907 which was the apex of the agreements between Russia and Britain in which they recognized the buffer situation of Afghanistan and Iran, divided Iran into two influence area including influence area of Russia in the North, influence area of Britain in the South, and an area between these areas as a control area of the state. The main objective of the creation of an area as a control area of the state was to prevent these powers' military confrontation that competed for their interests in Iran.

\section{Characteristics and Traits of Buffer Spaces}

Geographic location is a main factor in the creation of buffer space. Location is one of the basic factors that cause the buffer space to be formed. 
Neighborhood and geopolitical location have the most important role in buffer spaces. Based on the this fact that the closest neighbor is the main source of concern, when a weak state is neighboring with a powerful state, the weak state is always the cause of concern of the powerful state because there is always a threat that other powerful states use the weak state space to attack its space. Hence, the powerful state tries to annex the weak state to its territory or attract the weak state to its influence area or security treaties. In this situation buffer space is converted to semi-buffer.

Neighborhood location increases in the possibility of conflict. Korea located between three powerful states (Japan, china, Russia). These powerful states felt insecurity and feared from that this space is occupied by the other great powers. So, Korea has suffered from influence of these great powers and these states have agreed on the situation of buffer and not to encroachment on Korea.

Geopolitical and neighborhood location of Iran with Russia in the North and Britain (India) in the Southeast caused that these powerful states feel insecurity from this space side, and they did not intended to allow the rival state to enter this space in their offensive strategies. So the rival powers agreed on the being buffer, independence and neutrality of Iran and Afghanistan.

The buffer space investigated in this research is a space that have sovereignty and political independence. The buffered powers agree on the independence of buffer space and keep its independence until the balance of power is hold. This characteristic can be seen in the different buffers like in Korea, Belgium, Lebanon, Afghanistan, Iran etc.

The most important characteristics of the buffers' foreign policy is taking neutrality. Because buffer is threatened by rival powers, it tries to take neutrality in order to prevent the buffered powers invasion. Buffer acknowledges that it cannot confront with the buffered spaces. Neutrality shows the weakness of buffer space in confrontation with buffered states. If neutrality is enunciated by buffered states, it would kept by them, but if neutrality is enunciated by buffer state, it would not be kept. Occupation of Iran in the First and Second World Wars were evidences of this claim.

Beside of neutrality policy, buffers try to cooperate with a third power to reduce the pressure of buffered powers. This policy is taken when buffer sees keeping its neutrality and independence under pressure of buffered powers difficult. Therefore, the buffer space inclines to a third power to make the balance of power in its favor. In the two past centuries, Iran took the policy of turning to a third power: resorting to Britain in the Safavid era, to France in Qajar era, to Germany in the first Pahlavi era and to the US in the second Pahlavi era. But each time, buffered states showed negative reaction and 
increased in their pressure. So, alliance with third power as a non-neighboring power is not a secure strategy for the buffer, because the third power do not have a commitment to protect the independency and sovereignty of buffer when a conflict is started.

Buffer space is a space of competition between buffered states in social, economic, political, military and industrial facets. They arrange their players in the buffer and try to make the most of interests and prevent the other great powers to enter into this space. From the other hand, buffered states agree on independency of buffer, namely accept the buffer space between themselves and show that they are not intended to clash with each other. If buffer is put under the influence of a great power, the balance of power is broken. The first treaty between Russia and Britain on make Iran a buffer space was signed in I834, that Britain claimed Russian politicians to guarantee Iran's independency and territorial integrity as a buffer states between two great powers. This situation lasted two centuries, and Russia and Britain strategic interests in Central Asia, and Indian Subcontinent made it inevitable to create a buffer space.

In the first of 2oth century, four treaties were signed between Russia and Britain on Iran which show hard buffer situation of Iran. These are as follows: The treaty of 1907 that divided Iran into two influence areas between Russia and Britain and an influence area of the Iranian state; the treaty of I9I5 that divided Iran into two influence areas between Russia and Britain; the treaty of I9I9 that were imposed by Britain on Iran and the treaty of I92I that two great powers accepted Iran as a buffer between themselves.

The other characteristic of buffer space which is attractive for great powers is the strategic importance of buffer space. A space is attractive for powerful states when it is strategic. The most important factors which were attractive for great powers and caused competition were as follows: neighboring with India in the Southeast, neighboring with Russia in the North, energy resources, geopolitical location and locating at the meeting place of Asia, Africa and Europe.

Buffered states try to annex buffer space to their security-defensive area. Belgium and Afghanistan were under the threat of collapse because buffered states did not have the power to annex them to their territories. Vietnam and Korea were disintegrated in the competition of buffered states. Cambodia were not disintegrated, because one of the buffered states won the competition, and the structure of buffer were collapsed. Vietnam and Korea were disintegrated, because none of the buffered states won the competition, and could not take the control of the territory.

Decrease in the power of one of buffered states bring the occupation 
of a buffer space by the other buffered state. This issue occurred two times in Afghanistan. When Britain withdrew its forces from Indian Ocean, and the US has taken the management of the region, the Soviet Union benefited from power vacuum and attacked on Afghanistan in I979. The second one occurred in I99I when with the collapse of the Soviet Union, Russia withdrew from Afghanistan that paved the way for occupation of this contrary by the US.

If the buffer state had undertaken a hostile policy toward buffered states, the multifaceted pressure is formed on the buffer to the point that it would be forced to change its foreign policy. The imposed war (Iran-Iraq war) was the result of Iran's foreign policy.

\section{Functions of the Buffer Geographic Space}

Buffer space decreases the possibility of conflict between two great neighboring countries and buffered states, and if it cannot play this role, it would be converted to a clash arena of great neighboring states or as a path for invading forces. Britain and Russia did not confront with each other in Asia, because they knew the rivals increasing power, and for this reason the creation of a buffer space was the best option. Creating Iran and Afghanistan as buffer spaces caused sustainable peace between Britain and Russia.

Buffered states try to attract buffers in their coalitions and treaties, and prevent a buffer space to be attracted into the rival's influence area. The first coalition between Iran and a Western state was the treaty with Britain in I8o w when Britain appealed Iran helps to repel Afghans attacks to India in the framework of an offensive coalition. Baghdad defensive treaty which was an American innovation was signed by Britain, Turkey, Iraq, Iran and Pakistan in I955. Iraq withdrew from this treaty in 1958 , and the other members stablished SENTO treaty.

Buffered states show high level of sensitivity to the relations of buffer state with the other great powers, and monitor these relations, and put the buffer state under pressure. The worst scenario for buffered states is its inclination of a buffer state to a third power. Whenever Iran inclined to a third power, it was faced with Russia and Britain's negative reactions, and sometimes it resulted in the alliance of these powers to confront with the third power. Iran was encouraged to enter in the great game with the appeal of France in 1800 in order to confront with Russia and Britain. Russia and Britain did not intended to accept the presence of a third power in Iran. The most important third power was Germany, and Russia and Britain feared the 
increase of the power of Germany in Iran and Europe.

The two buffered states monitor the rival's behavior in the buffer space and show reaction in this regard. There are many cases in which buffered states have committed to different means like military invasion, occupation, strikes, boycotts, and threats in reaction to the rival's behavior in the buffer space.

\section{The Behavior of Native Political Actors and the Citizens' Attitude in the Buffer Spaces}

In governmental level, buffered states always intervene in the buffer space. This issue is seen in all buffers like in Korea, Belgium, Afghanistan, and Iran etc. to the point that Russia had showed reaction to the treaties signed between Iran and Britain and threatened Iran. Also, Britain had taken this behavior against Iran. These interventions were increased when Britain was replaced by the US, and after the Islamic republic these pressures were increased intensely by the buffered states (the US and Russia).

Elites and actors of political arena of buffer spaces incline to one of buffered states which increase the disabilities of their states, and also bring more influence of buffered states. Political behavior of different governments in Iran in the two last centuries in relation with great powers has not been the same, and each government has taken special behavior. Meanwhile, some politicians were accused of partiality towards special states; sometimes they cooperate with great powers and sometimes were famous for moderation or hatred of a special state. Also, some of them did not know that to which of the great powers they incline. Most of the political happenings in the buffer state are not spontaneous and are resulted from buffered states rivalries.

Buffers are faced with political challenges because of the influence and pressure of buffered states, and they are deprived from taking an independent internal and external policies. The buffers disputes with the neighboring countries and with the other states bring isolation of the buffer. This situation may run buffer afoul of lack of functional integrity, and each organ of the state incline to one of buffered states. From the other hand, buffer states take sometimes the policy of de-utilization to decrease in the concerns of buffered states. So, the weakness of the buffer is continued, and political decisions are made reactionary. Decision and policy makings in buffer space are sometimes resulted from political wills of the powers and their positive and negative reactions, and are also temporary, reactionary, and without comprehend plan.

The most important function of the buffers in social level is political, 
social, economic and cultural vulnerabilities. In the last two centuries, the pressures of the buffered states have caused Iran face with high political, social, economic and cultural, military and security defeats. Two centuries influence, rivalry, conflict of interests of buffered states which have brought occupation, war, sanctions, intervention in internal affairs, lack of development, military defeats, poverty and famine for Iran, is resulted in vast vulnerabilities in Iranians' life.

People living in a buffer space take different policies and tactics and sometime incline to a third power or take neutrality in order to get free of pressures resulted from rivalry of buffered states. They perceive that the politicians and elites' triumphs are not successful to avert the pressures of buffered states, and consequently incline to great powers to solve their problems. So, buffer space people find a cynical attitude towards buffered states and a sense of xenophobia is formed. Xenophobia has been one of most important factors in the formation of Iranian movements and riots. This sense was apparent in the Constitutional Movement, and also it was the motif of main slogans of the people during the Islamic Revolution.

With the intervention of buffered states Iranian people perceived that they do not have the right of self-determination, and the great states impose their wills on Iran. So, the cynical attitude was formed toward politicians, and state organs, and people knew the governments as puppet rule of buffered states, and avoid to cooperate with them. In this situation, protests and nationalist, and liberation movements and sometimes separatist movements are formed, and these movements find social supports.

In a buffer space accusations and suspicions and ill will and suspicion of spying, mercenary, and being a foreign agent towards politicians are increased. Permanent intervention of buffered states in Iran's internal affairs, inevitable inclination of Iranian elites to one of the powers, lack of the parties and grassroots organizations to direct public opinion and public campaigns cause people do not trust in political actors, and to have negative point of views to their actions. This goes so far as the public, in teased or to joke, attributed every little problem to the Britain. When politicians wanted to oppose or criticize the rule, people had cynical point of view to them, and claimed that the politicians are agents of foreigners or are opportunists. This has caused that the movement of educated people and elites in Iran is not welcomed, and the only movements that are welcomed are in line with the spirit of their religion and in opposition with all great powers (not to cooperate symmetrically with them). 


\section{The Current Situation of Iran}

Iran has taken hostile neutrality policy towards the East and West after the Islamic Revolution. Iran's failure in meeting its ideological needs and neighboring states caused an ideological vacuum. Lack of experience and taking a new aggressive policy of neutrality caused power vacuum in Iran and in the region which was consequently resulted in the war against Iraq.

The other characteristic of the buffers is that if it is faced with the threat of collapse, it is inclined to a great neighboring state. At the end of the Iran-Iraq war, Iran leaned towards the Soviet Union, and the slogan of "down with the Soviet Union" were removed from public slogans of Iranians. Consequently, the pressure of the East (as a buffered state) were removed, and the war ended and Iran was found in the semi-buffer situation.

Iran's strategic considerations in the past two centuries have been linked to the strategic considerations of buffered states, and it has not had an independent strategic consideration in codification of social, economic, cultural, political, military policies. The semi-buffer situation of Iran and the undertaking of a hostile policy (toward one of the buffered states) have caused Iran to be deprived from international cooperation, and decreased its bargaining power in global and regional arena, hindered regional integration (without supra-regional powers), prevented the adoption and follow-up of development policies, prevented an increase in foreign incomes and economic growth (despite rich hydrocarbons resources). In this situation Iran cannot benefit from its geopolitical and geo-economic potential to develop in different facets.

Because of the situation imposed by geography on a buffer sate, it should codify its internal and external policies by considering its geographical and geopolitical realities, and lack of attention to these facts and also geopolitical situation of the state led to a decrease in its power and capacity and public development and growth. 
Figure 5. Iran's Semi-Buffer Situation

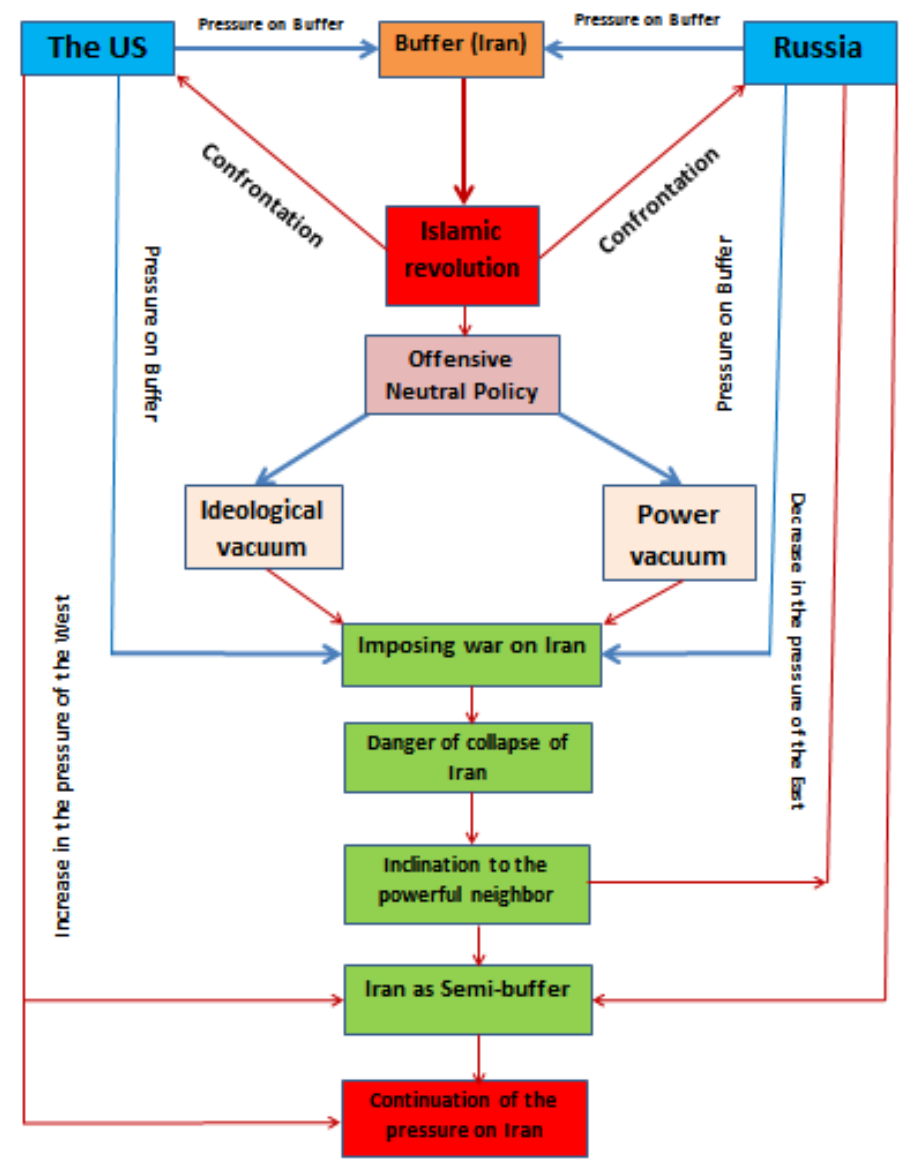

(Ahmadi 2015, 35)

\section{Acknowledgement}

I would like to thank my Thesis supervisor, Pr. Hafeznia and my two advisors: Pr. Bernard Hourcad (Emeritus Professor at CNRS-France) and Pr. Pirooz Mojtahedzadeh and thank the Research Deputy of Tarbiat Modares University in compiling and editing this research. 


\section{REFERENCES}

Ahmadi Nohadani, Syrus \& Ghorbaninejad, Ribaz. (2005). Scientific theories in political geography and geopolitics. Center of Excellence in Political geography, Tarbiat Modares University. Mashhad: Papali Press.

Ahmadi Nohadani, Syrus. (2013). Finding pattern of political character of geographical buffer space: case study: Iran. PhD dissertation, supervised by Mohammad-Reza Hafeznia. Tehran: Tarbiat Modares University.

Ahmadi, Seyed Abbas \& Parsaeei, Esameil. (2005). Iran's position in the geopolitical theories. The second congress of the Iranian Association of geopolitics, Iranian Association of geopolitics, Tehran, Iran.

Ahmadi, Syrus. Explanation of the Functions of Iran's buffer Status in the past Two Centuries, (2015), Geopolitical Journal, V.ı2. (SCOPUS).

Ahmadi, Syrus. Explanation the structural-functional characteristics of geographical buffer spaces, (2013B), Geopolitical Journal, V.8, No.28. (SCOPUS)

Ahmadi, Syrus, Geopolitics of Buffer Spaces: Characteristics of Iran's Buffer Situation Between Great Powers in the Nineteenth and Wentieth Century $(A D)$. (20I3A), Sciences. International. (Lahore), 25(4), IOI9-I030, I2OI3. (ISI)

Ali Soofi, Ali Reza. (2006). Impacts of Russia and Britain Rivalry in Forming Mashrute Revolution. Journal of Economic- Political Information, No. 227-230, P.P: I28-I39. (in Persian Language).

Bashirie, Hussein. (200I). Obstacles to political development in Iran. Tehran: Game Now Press.

Chay, John. (I986). Korea, a Buffer State in World Politics, ed. John Chay and Thomas Ross, (Boulder: Westview Press).

Corm, G.. (2007) ; L'Evolution du statut du Liban dans l'ordre régional et international (1840-2005), Colloque tenu le 29 septembre 2007 a l'Auditorium de la Maison du Barreau de Paris, intitulé : le Liban dans l'ordre juridique international.

Ezzati, Ezzatollah \& Kiyumars Yazdanpanah (2007). Analysis of the Geopolitics of Shanghai Cooperation Organization with Emphasis on Iran's Membership. Geopolitics Quarterly, No 3. (in Persian Language)

Ezzati, Ezzatollah. (2003). Geopolitics in 21th century. Samt Press. (in Persian Language)

Fouler, Graham. (I994). World Qibla, Iran's Geopolitics. Translated by: Abbas Mokhber. 4th print, Tehran: Markaz Press.

Fox, A.B.. (1959). The Power of Small States. Chicago, Univ. of Chicago Press. Ghafari Hashtjin, Zahed. (2003). The role of foreign forces in the establishment 
and development of conspiracy theory in Iran from the Constitution Revolution to Islamic Revolution. Economic and Political Information Journal, pp. I9I-I92.

Hannah, N. B. (I979). Afghanistan: The Great Gamble, Asian Affairs, An American Review, 6 janurary-Februry.

Homayoon katoozian, Mohammad Ali. (2010). Political economy of Iran from the Constitution Revolution to the end of the Pahlavi dynasty, translated by Reza Nafisi and Kambiz Azizi, I6th edition, Tehran: Markaze -Nashr Press.

Hooshang Mahdavi, Abdolreza. (2009). Iran's foreign relations history, from the beginning of the Safavid period to the end of World War II, i4th edition. Tehran: Amir Kabir Press.

Ingalls, G. L.. (1986); Buffer States: Outlining and expanding existing theory, (Chapter I2), in Chay, John and Thomas, E. Ross (edited by), Buffer States in World Politics, U.S.A, Westview Press.

Jenkins, B. D.. (1986); The History of Afghanistan as a Buffer State, (Chapter 9), in Chay, John and Thomas, E. Ross (edited by), Buffer States in World Politics, U.S.A, Westview Press.

Kempp, O.. (2008); Etat pivot, EGEA, Etudes geopolitiques et Atlantiques, vendredi 3I octobre, Available from: http://egea.over-blog.com.

Maila, J.. (I986); Buffer States: The Issues of Soverneignty, in Chay, John and Thomas, E. Ross (edited by), Buffer States in World Politics, U.S.A., Westview Press.

Malakootiyan, Mostafa. (2004). an introduction to political gegraphy and geopolitical and strategic importance of Iran. Law and Political Science Journal, No. 63, pp. 203-22I, Tehran.

Manshoor Gorgani, Mohammad-Ali. (1989). The Soviet Union and Britain competition in Iran, from 1917 to 1927. Tehran: Ataie Press Institute.

Nezio, Pio Kar Loter. (1984). Russia and Britain Rivalry in Iran and Afghanistan. Translated By: Abbas Azin. Tehran: Sherkat Entesharat Elmi va Farhangi.

Partem, G. M.. (1983); The Buffer System in International relations, The Journal of Conflict Resolution (pre-I986) Vol. 27, No I; mars.

Rondeli, A.. (2003). The Small State in the International System. Tiblisi, Georgian Fondation for Strategic and International Studies, Metsniereba.

Ross, Thomas, (I986); Buffer State: a Geographer perspective, in Buffer State in World Politics, ed. John Chay and Thomas Ross, (Boulder: Westview Press).

Tulchin, J., S., (1986); Uruguy: the Quintessential Buffer State, (Chapter II) in Chay, John and Thomas, E. Ross (edited by), Buffer States in World Politics; U.S.A,Westview Press. 
Turmanidze, Tornike. (2009). Buffer States, Power Policies, Foreign Policies and Concepts; in Global Political Studies Series. Nova Science Publishers, Inc, New York.

Warrin, F.L., J.. (I9I8). The Neutrality of Belgium. Washington DC: Government Printing Office.

Wight, Martin. (I995). Power Politics, ed. Hedley Bull and Carsten Holbraad. London: Leicester University Press, Royal Institute of International Affairs.

Ziring, Lawrence. (I986). Asia's Pivotal Buffer States, In Buffer States in World Politics, ed. John Chay and Thomas Ross, Boulder: Westview Press. inc. U.S.A.

\section{ABSTRACT}

With the occupation of India by one of the global powers namely Britain (I770), and its territorial expansion toward the West and Iran's borders, Russia (the other global power) started its expansion and moved towards the Indian Ocean and Iran's north borders from the first of I9th century (I804-I8I3/ I826/I828). Britain from East and South and Russia from North entered into Iran's borders, and buffered Iran and Afghanistan in order to not to separate them form each other. In the rivalry pattern of buffered states, their geographic spaces should be separate. Low power geographic space is required between the powers. Geopolitical boundaries of these two powers should not get into contact because in such a case, the possibility of conflict can arise. So, the buffer space takes the form of vacuum space between the buffered powers. The research main question is that what is the nature, functions, characteristics and political behavior of a geographic buffer space? Which geographic values and functions cause buffer space to be a buffer space and attract great powers? In this research, a new definition of buffer space is presented, and the process of formation of buffers (the whys and wherefores), functions and characteristics of buffers in two internal and external dimensions are investigated. Then, the validity of the variables is investigated using library and field findings, and is used in the process of evaluation of internal and external experts. The results are analyzed using statistical methods and SPSS. Finally, these variables are evaluated in the context of Iran.

\section{KEYWORDS}

Buffer Space; Buffer States; Geopolitics; Iran; Powers Rivalry.

Received on October 5, 2019 Approved on May 8, 2020 